\title{
Statin Administration Does Not Improve the Mobilization of Very Small Embryonic-Like Stem Cells (VSELs) in Contrast to Resveratrol Treatment in a Murine Model of Acute Myocardial Infarction
}

\author{
H. WANG ${ }^{1}$, Y.-J. YANG ${ }^{1}$, H.-Y. QIAN ${ }^{1}$, Q. ZHANG ${ }^{1}$, L.-J. GAO ${ }^{1}$, P. LI ${ }^{1}$, T.-J. WANG ${ }^{1}$, \\ S.-D. WANG ${ }^{2}$
}

${ }^{1}$ State Key Laboratory of Translational Cardiovascular Medicine, Fuwai Hospital and Cardiovascular Institute, Chinese Academy of Medical Sciences and Peking Union Medical College, Beijing 100037, ${ }^{2}$ Institute of Chinese Materia Medica, China Academy of Chinese Medical Sciences, Beijing 100070, P.R. China

Received May 24, 2012

Accepted August 31, 2012

\begin{abstract}
Summary
We have found that short-term statin treatment plus stem cell transplantation in acutely infarcted hearts improves cardiac function because statins promote the efficacy of cellular cardiomyoplasty. Autologous Sca- $1^{+} \mathrm{Lin}^{-} \mathrm{CD} 45^{-}\left(\mathrm{CXCR}^{+}\right)$very small embryonic-like stem cell (VSEL) mobilization in acute myocardial infarction (AMI) correlates with the preservation of cardiac function. Whether short-term atorvastatin (Ator) can enhance the mobilization or recruitment of VSELs in AMI is still unclear. We divided mice into 4 groups: 1) sham; 2) AMI; 3) AMI+resveratrol (RSV) as a positive control; and 4) AMI+Ator. There was an increase in the circulating VSEL/full population of leukocytes (FPL) ratio 48 hours after $\mathrm{AMI}$, and $\mathrm{AMI}+\mathrm{RSV}$ increased it further. Ator administration did not increase the VSEL/FPL ratio. The cardiac stromal cell-derived factor-1 (SDF-1) and SDF-1a levels were in agreement with the results of VSEL mobilization. One week after AMI, more Sca- $1^{+} \mathrm{CXCR}^{+}$cells were recruited to the myocardium of AMI+RSV mice but not AMI+Ator mice. Short-term Ator administration failed to upregulate cardiac SDF-1 and could not enhance the recruitment of VSELs early after AMI.
\end{abstract}

\section{Key words}

Very small embryonic-like stem cells $\bullet$ Acute myocardial infarction - Atorvastatin • Stromal cell-derived factor-1

\section{Corresponding author}

Yue-jin Yang, Centre for Coronary Heart Disease, Department of Cardiology, Fuwai Hospital and Cardiovascular Institute, Chinese
Academy of Medical Sciences and Peking Union Medical College, 167 BeiLiShi Rd, Xicheng District, Beijing, 100037, P.R. China. Fax: +86 10 68351786. E-mail: yangyjfw@yahoo.com.cn

Stem cell-based therapies are promising procedures for myocardium regeneration (Singh et al. 2009) after acute myocardial infarction (AMI), and these therapies include stem cell mobilization and transplantation. The mobilized cells can participate in organ repair naturally or can be concentrated in vitro for transplantation. Although the transplantation of bone marrow-derived stem cells (BM-SCs) has been proven to be safe and effective, improvement of the left ventricular ejection fraction (LVEF) is still limited. We have confirmed that one week of statin treatment in AMI improves the cardiac micro-environment created by AMI, facilitates the survival and differentiation of implanted stem cells, and increases LVEF compared with stem cell transplantation models (Yang et al. 2008). However, whether the beneficial effects of statins on the cardiac function improvement in these experiments are partially mediated by mobilizing myogenic stem cells is still unclear.

The BM-SCs released into peripheral blood after AMI consist of hematopoietic stem cells (HSCs, approximately $40 \%$ of $\mathrm{CD} 34^{+} \mathrm{HSCs}$ are $\left.\mathrm{CXCR}^{+}\right)(\mathrm{Wu}$ et al. 2009), endothelial progenitor cells (EPCs, 
approximately $20 \%$ of which are CXCR $4^{+}$) (Garolla et al. 2009), and very small embryonic-like stem cells (VSELs) (Wojakowski et al. 2009, Zuba-Surma et al. 2008). HSCs and EPCs are possibly progenitor cells that arise from VSELs (Bhartiya et al. 2012), which have recently been identified in mice and humans as populations of very small Sca- $1^{+} \mathrm{Lin}^{-} \mathrm{CD} 45^{-}$cells $(82 \%$ of which are $\left.\mathrm{CXCR}^{+}\right)$and very small $\mathrm{CD} 34^{+} \mathrm{CD} 133^{+} \mathrm{Lin}^{-}$ CD45 $\left(\mathrm{CXCR}^{+}\right)$cells, respectively. VSELs exhibit better myocardium differentiation and beneficial effects on improving cardiac function after AMI (Dawn et al. 2008, Wojakowski et al. 2009, Wojakowski et al. 2010, ZubaSurma et al. 2008).

The stromal cell-derived factor-1 (SDF-1)/ CXCR4 (the receptor of SDF-1) axis may play an essential role in the mobilization of VSELs from the BM. SDF-1 attracts VSELs in direct chemotactic studies, and the number of circulating VSELs in MI patients positively correlates with the plasma level of SDF-1 (Kucia et al. 2006, Wojakowski et al. 2009). We have found that resveratrol (RSV) enhances VSEL mobilization in the early stage of AMI via upregulating cardiac SDF-1 (Wang et al. 2011). Whether statins have similar effects as RSV is unknown. To clarify the effect of statins on VSEL mobilization in AMI, we used AMI+RSV mice as a positive control and examined the effect of atorvastatin (Ator).

The experimental design was approved by the Ethics Committee of the Chinese Academy of Medical Sciences and Peking Union Medical College. Animal care and experimental procedures were conducted in accordance with the European Guidelines on Laboratory Animal Care. Male C57BL/6 mice that were 8-10 weeks old were randomly divided into sham; AMI; AMI+RSV (Sigma, $25 \mathrm{mg} / \mathrm{kg} /$ day in drinking water, one week); and AMI+Ator (Pfizer, $25 \mathrm{mg} / \mathrm{kg} /$ day in diet, one week) groups. Because VSEL mobilization peaks at 48 hours after AMI and Sca- $1^{+}$cell recruitment in the infarcted area is obvious at one week after AMI (Zuba-Surma et al. 2008, Zhang et al. 2007), mice were sacrificed at these two time points.

After five days of drug loading, mice were anesthetized with an intraperitoneal injection of chloral hydrate $(20 \mathrm{ml} / \mathrm{kg})$, endotracheally intubated by tracheotomy, and mechanically ventilated using the Inspira-Advanced Safety Ventilator (Harvard Corp.). After exposing the heart via a left thoracotomy and removing the pericardium, the left anterior descending coronary artery $(\mathrm{LAD}, 2 \mathrm{~mm}$ below the tip of the left auricle) was occluded with an 8.0 Prolene suture (ETHICON, Inc.). Occlusion was confirmed by observing the LV pallor immediately after ligation or the measurement of serum creatine kinase MB isoenzyme (CK-MB) 48 hours after AMI. Serum cholesterol was evaluated together with CK-MB (Beckman Coulter automatic biochemical analyzer, $n=4-5$ in each group).

Flow cytometry analysis and VSEL sorting were performed as described previously (Zuba-Surma et al. 2008), with minor modifications. The full population of leukocytes (FPLs, $n=6-8$ in each group) in the arterial blood $(500 \mu \mathrm{l})$ was obtained using erythrocyte lysis buffer (Becton Dickinson Pharmingen) and stained for lineage cocktail (APC), CD45 (PE), and Sca-1 (FITC) according to the manufacturer's instructions (Miltenyi Biotec.). The cell sizes of the FPLs were determined by the AccuCount Blank particles ACBP-20-10 $(2 \mu \mathrm{m})$ and ACBP-100-10 $(10 \mu \mathrm{m})$ (Spherotech, Inc.) using flow cytometry (Becton Dickinson).

LVs were isolated after drawing blood and kept at $-80{ }^{\circ} \mathrm{C}$ until use. Protein ( $\mathrm{n}=4$ in each group) was extracted from LVs through homogenization in RIPA buffer. Western blotting was performed with an antiSDF-1 (Cell Signaling Technology) antibody. Signals were quantified with Scion Image Software and standardized to the expression of $\beta$-actin (Sigma). SDF$1 \alpha$ is a predominant isoform of SDF-1 (Wen et al. 2012) and was measured with a mouse ELISA kit (RayBiotech Inc.). Approximately $0.05 \mathrm{~g}$ of infarct (approximately $0.02 \mathrm{~g}$ ) and peri-infarct tissues each were cut out of the LVs, washed, homogenized in ice-cold $0.9 \% \mathrm{NaCl}$ solution, and centrifuged. The clear supernatant was kept on ice for the assay ( $\mathrm{n}=8$ in each group) according to the manufacturer's instructions.

One week after AMI, frozen sections of the heart $(n=3-4$ in each group) were immunostained with antiSca-1 (1:10, Miltenyi Biotec.) and anti-CXCR4 (1:100, Abcam) antibodies. Cells that were double positive for CXCR4 and Sca-1 proteins were counted in 15 highpower fields $(\mathrm{HPF}, \times 400)$ in the infarct and peri-infarct regions.

All values were expressed as the means \pm SEMs. The statistical analysis was carried out with an ANOVA followed by Fisher's method. A value of $p<0.05$ was considered significant.

After AMI, CK-MB increased (sham:

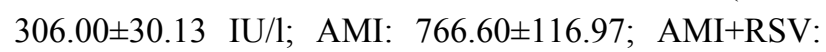
664.20 \pm 84.73 ; AMI+Ator: $579.00 \pm 52.54$, Fig. 1A), but the cholesterol levels showed no difference (sham: 
$2.22 \pm 0.17 \quad \mathrm{mmol} / \mathrm{l} ; \quad$ AMI: $2.19 \pm 0.06 ; \quad$ AMI+RSV: $2.47 \pm 0.23$; AMI+Ator: $2.09 \pm 0.15)$. FPLs were counted during flow cytometry analysis. The number of leukocytes increased after AMI, although not significantly (Fig. 1B). To avoid the influence of transient leukocytosis, the VSEL/FPL ratio was analyzed, and it was increased approximately $4(3.89 \pm 0.53)$ times in the AMI group and nearly $7(7.35 \pm 0.84)$ times in the AMI+RSV group. However, AMI+Ator (VSEL/FPL: 4.07 \pm 0.65 ) did not mobilize more VSELs (Fig. 1C, D). Compared with sham mice, the cardiac SDF-1 expression in AMI mice increased. AMI+RSV mice had the highest cardiac SDF-1, and AMI+Ator mice failed to show increased levels (Fig. 2A, B). The levels of SDF-1 $\alpha$ in infarct and peri-infarct tissues of each group (sham: $187.43 \pm 5.32 \mathrm{pg}$ SDF-1 $\alpha / \mathrm{mg}$ tissue; AMI: $249.83 \pm 16.13$; AMI+RSV: $318.39 \pm 15.24$; AMI+Ator: $251.66 \pm 27.85$, Fig. 2C) were consistent with the results of western blotting. Compared with AMI mice (0.53 $\pm 0.19 / \mathrm{HPF})$, Sca- $1^{+} \mathrm{CXCR} 4^{+}$cells in the myocardium of $\mathrm{AMI}+\mathrm{RSV}$ mice $(1.47 \pm 0.32)$ but not AMI+Ator $(0.40 \pm 0.19)$ mice were increased (Fig. 2D).
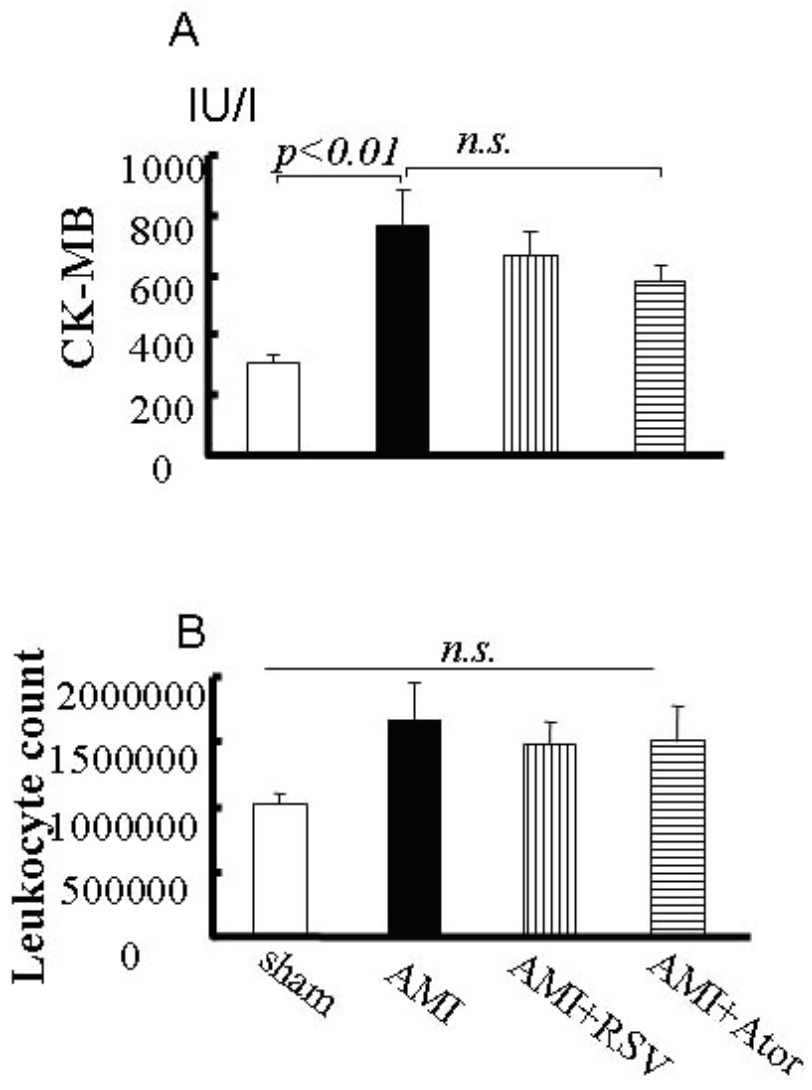
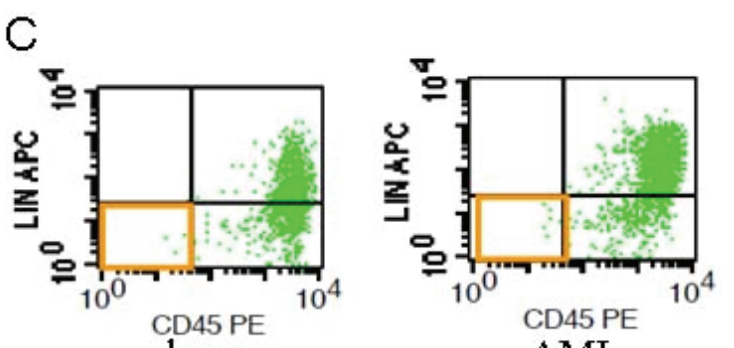

sham
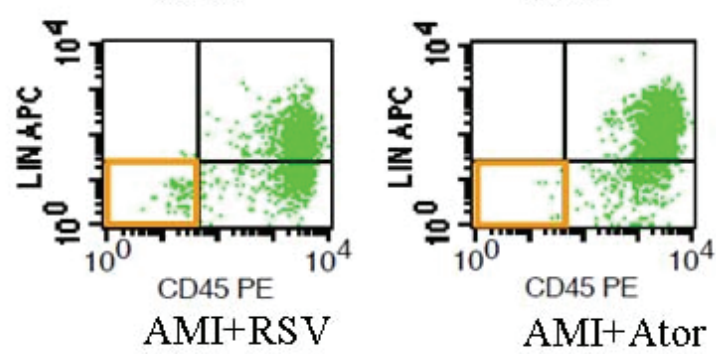

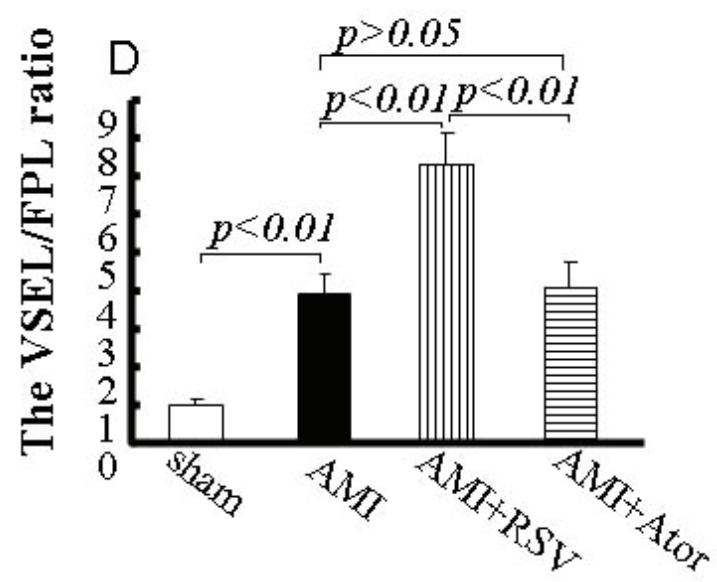

Fig. 1. Isolation and count of circulating VSELs after AMI. A. CK-MB increased in the mice with LAD ligation. B. FPL count during flow cytometry analysis. C. Representative flow cytometry images of the sham, AMI, AMI+RSV, and AMI+Ator groups. Flow cytometry analysis was based on the size and immunophenotype of the VSELs. The leukocytes sized 2-10 $\mu \mathrm{m}$ and positive for Sca-1 were identified first, then LinCD45 VSELs (orange squares) were selected. D. Circulating VSELs standardized by the number of FPLs. n.s.: no significant difference among all groups.

VSELs mobilize to peripheral blood after AMI as a self-repair approach, and the number of circulating VSELs correlates positively with LVEF (Wojakowski et al. 2009). For various reasons, SDF-1 expression is increased in cardiac tissue soon after myocardial infarction and sustained for 5-7 days following AMI (Wang et al. 2006, Wen et al. 2012). Consistently, VSEL mobilization reaches a peak at 48 hours and returns to 
control levels at 7 days after AMI (Kucia et al. 2004, Zuba-Surma et al. 2008). Statins can mobilize EPCs under different conditions, including normal conditions, acute vascular injuries, cardiac ischemia, obesity and chronic heart failure. Moreover, short-term statin loading is sufficient to increase EPC mobilization (Hibbert et al. 2011, Hong et al. 2010, Shao et al. 2008, Thum et al. 2006, Tousoulis et al. 2011, Westerweel et al. 2008). Although statins can influence the mobilization of SCs, a recent report on VSEL mobilization did not perform a subgroup analysis of whether statins were taken (Wojakowski et al. 2009). These results motivated us to determine whether one week of statin treatment mobilized VSELs at the same time as it improved cardiac micro-environments created by AMI (Yang et al. 2008). Unfortunately, in the current study, we found that shortterm Ator failed to enhance the mobilization of VSELs early after AMI ( $5 \mathrm{mg} / \mathrm{kg} /$ day Ator to AMI mice showed similar result).

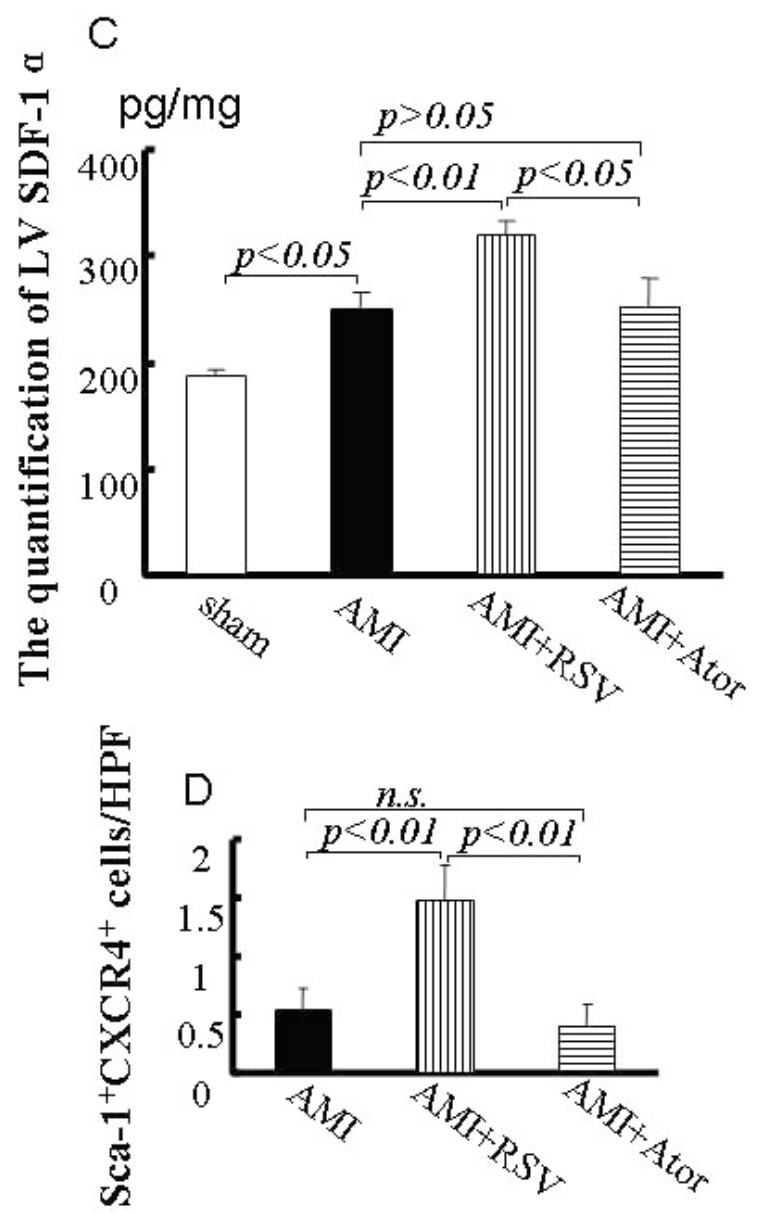

Fig. 2. SDF-1 evaluation and the detection of Sca- $1^{+} \mathrm{CXCR} 4^{+}$cell recruit in cardiac tissue. A. Representative immunoblots of SDF- 1 in LV. B. The bar graph showed the quantification of the immunoblots. C. The quantification of SDF-1a (infarct and peri-infarct areas) by ELISA. D. Sca- $1^{+} \mathrm{CXCR} 4^{+}$cells in the infarct and peri-infarct regions/HPF.

Consistent with the previous report (Hsu et al. 2010), we found that SIRT1 expression in infracted LV was decreased (Wang et al. 2011). p53 acts upstream of SDF-1. SIRT1 inhibition activates p53 and thus hinders the upregulation of SDF-1 (Addadi et al. 2010, Wang et al. 2011 and 2012, Olive et al. 2008) after AMI. Through SIRT1 activation, RSV increases SDF-1 and the mobilization of VSELs. However, short-term Ator administration in AMI did not improve the expression or secretion of SDF-1 in the infarcted heart.

VSELs are usually quiescent in the adult BM. A hypomethylation of paternally methylated imprints and a hypermethylation of maternally methylated ones are observed at some crucial developmentally genes in isolated BM VSELs. This modification leads to the upregulation of growth-repressive genes and the repression of growth-promoting genes (Shin et al. 2009). Therefore, the rapid expansion of VSELs is still difficult. 
In contrast, the expansion of EPCs is much easier. Many studies suggest that statins promote the proliferation/ differentiation and inhibit the death of EPCs (Shao et al. 2008, Thum et al. 2006). A step-forward multivariate linear regression analysis found that EPC number was inversely related to plasma SDF-1 $\alpha$ (Xiao et al. 2007). More interestingly, a study in pulmonary artery injury showed that statins downregulated SDF-1 (Satoh et al. 2009). All of these results support that the mechanism of EPC mobilization is potentially different from VSEL mobilization.

The result of the current study is in accordance with our previous report that one week of Ator treatment $(0.25 \mathrm{mg} / \mathrm{kg} /$ day without stem cell transplantation in swine) had little effect on cardiac regeneration (Yang et al. 2008). However, the beneficial activities of statins on chronic systolic cardiac insufficiency (Zhang et al. 2011) are undoubted. The pleiotropic effects of statins, such as the protection of endothelial function, antioxidant effect, anti-inflammatory reaction and the prevention of apoptosis, are important for cardiac function recovery.

\section{Conflict of Interest}

There is no conflict of interest.

\section{Acknowledgements}

We gratefully acknowledge the technical assistance (flow cytometric analysis) of Feng-jun Xiao (Academy of Military Medical Sciences; Beijing, China). This study was supported by grants from the National Natural Science Foundation of China (81070169 and 81170129), the China Health \& Medical Development Foundation (2008-zhfj2 and 2011-H25), and the Ph.D. Programs Foundation of Ministry of Education of China (20111106110012).

\section{References}

ADDADI Y, MOSKOVITS N, GRANOT D, LOZANO G, CARMI Y, APTE RN, NEEMAN M, OREN M: p53 status in stromal fibroblasts modulates tumor growth in an SDF1-dependent manner. Cancer Res 70: 9650-9658, 2010.

BHARTIYA D, SHAIKH A, NAGVENKAR P, KASIVISWANATHAN S, PETHE P, PAWANI H, MOHANTY S, RAO SG, ZAVERI K, HINDUJA I: Very small embryonic-Like stem cells with maximum regenerative potential get discarded during cord blood banking and bone marrow processing for autologous stem cell therapy. Stem Cells Dev 21: 1-6, 2012.

DAWN B, TIWARI S, KUCIA MJ, ZUBA-SURMA EK, GUO Y, SANGANALMATH SK, ABDEL-LATIF A, HUNT G, VINCENT RJ, TAHER H, REED NJ, RATAJCZAK MZ, BOLLI R: Transplantation of bone marrow-derived very small embryonic-like stem cells attenuates left ventricular dysfunction and remodeling after myocardial infarction. Stem Cells 26: 1646-1655, 2008.

GAROLlA A, D'INCÀ R, CHECCHIN D, BIAGIOLI A, DE TONI L, NICOLETTI V, SCARPA M, BOLZONELLO E, STURNIOLO GC, FORESTA C: Reduced endothelial progenitor cell number and function in inflammatory bowel disease: a possible link to the pathogenesis. Am J Gastroenterol 104: 2500-2507, 2009.

HIBBERT B, MA X, POURDJABBAR A, SIMARD T, RAYNER K, SUN J, CHEN YX, FILION L, O'BRIEN ER: Pre-procedural atorvastatin mobilizes endothelial progenitor cells: clues to the salutary effects of statins on healing of stented human arteries. PLoS One 6: e16413, 2011.

HONG SJ, CHOI SC, KIM JS, SHIM WJ, PARK SM, AHN CM, PARK JH, KIM YH, LIM DS: Low-dose versus moderate-dose atorvastatin after acute myocardial infarction: 8-month effects on coronary flow reserve and angiogenic cell mobilization. Heart 96: 756-764, 2010.

HSU CP, ZHAI P, YAMAMOTO T, MAEJIMA Y, MATSUSHIMA S, HARIHARAN N, SHAO D, TAKAGI H, OKA S, SADOSHIMA J: Silent information regulator 1 protects the heart from ischemia/reperfusion. Circulation 122: 2170-2182, 2010.

KUCIA M, DAWN B, HUNT G, GUO Y, WYSOCZYNSKI M, MAJKA M, RATAJCZAK J, REZZOUG F, ILDSTAD ST, BOLLI R, RATAJCZAK MZ: Cells expressing early cardiac markers reside in the bone marrow and are mobilized into the peripheral blood after myocardial infarction. Circ Res 95: 1191-1199, 2004. 
KUCIA M, RECA R, CAMPBELL FR, ZUBA-SURMA E, MAJKA M, RATAJCZAK J, RATAJCZAK MZ: A population of very small embryonic-like (VSEL) CXCR4(+)SSEA-1(+)Oct-4+ stem cells identified in adult bone marrow. Leukemia 20: 857-869, 2006.

OLIVE M, MELLAD JA, BELTRAN LE, MA M, CIMATO T, NOGUCHI AC, SAN H, CHILDS R, KOVACIC JC, BOEHM M: p21Cip1 modulates arterial wound repair through the stromal cell-derived factor-1/CXCR4 axis in mice. J Clin Invest 118: 2050-2061, 2008.

SATOH K, FUKUMOTO Y, NAKANO M, SUGIMURA K, NAWATA J, DEMACHI J, KARIBE A, KAGAYA Y, ISHII N, SUGAMURA K, SHIMOKAWA H: Statin ameliorates hypoxia-induced pulmonary hypertension associated with down-regulated stromal cell-derived factor-1. Cardiovasc Res 81: 226-234, 2009.

SHAO H, TAN Y, ETON D, YANG Z, UBERTI MG, LI S, SCHULICK A, YU H: Statin and stromal cell-derived factor-1 additively promote angiogenesis by enhancement of progenitor cells incorporation into new vessels. Stem Cells 26: 1376-1384, 2008.

SHIN DM, ZUBA-SURMA EK, WU W, RATAJCZAK J, WYSOCZYNSKI M, RATAJCZAK MZ, KUCIA M: Novel epigenetic mechanisms that control pluripotency and quiescence of adult bone marrow-derived Oct $4(+)$ very small embryonic-like stem cells. Leukemia 23: 2042-2051, 2009.

SINGH S, ARORA R, HANDA K, KHRAISAT A, NAGAJOTHI N, MOLNAR J, KHOSLA S: Stem cells improve left ventricular function in acute myocardial infarction. Clin Cardiol 32: 176-180, 2009.

THUM T, FRACCAROLLO D, GALUPPO P, TSIKAS D, FRANTZ S, ERTL G, BAUERSACHS J: Bone marrow molecular alterations after myocardial infarction: Impact on endothelial progenitor cells. Cardiovasc Res 70: 50-60, 2006.

TOUSOULIS D, ANDREOU I, TSIATAS M, MILIOU A, TENTOLOURIS C, SIASOS G, PAPAGEORGIOU N, PAPADIMITRIOU CA, DIMOPOULOS MA, STEFANADIS C: Effects of rosuvastatin and allopurinol on circulating endothelial progenitor cells in patients with congestive heart failure: the impact of inflammatory process and oxidative stress. Atherosclerosis 214: 151-157, 2011.

WANG H, WANG J, HOU JF, QIAN HY, ZHANG Q, XU H, SONG L, JIN C, YANG YJ: Enhanced mobilization of Sca1+Lin-CD45-CXCR4+ stem cells after acute myocardial infarction by resveratrol preload is related with the deacetylation of cardiac p53. Cardiology 120 (Suppl 1): S44, 2011.

WANG H, YANG YJ, QIAN HY, ZHANG Q, XU H, LI JJ: Resveratrol in cardiovascular disease: what is known from current research? Heart Fail Rev 17: 437-448, 2012.

WANG Y, HAIDER HKH, AHMAD N, ZHANG D, ASHRAF M: Evidence for ischemia induced host-derived bone marrow cell mobilization into cardiac allografts. $J$ Mol Cell Cardiol 41: 478-487, 2006.

WEN J, ZHANG JQ, HUANG W, WANG Y: SDF-1a and CXCR4 as therapeutic targets in cardiovascular disease. Am J Cardiovasc Dis 2: 20-28, 2012.

WESTERWEEL PE, VISSEREN FL, HAJER GR, OLIJHOEK JK, HOEFER IE, DE BREE P, RAFII S, DOEVENDANS PA, VERHAAR MC: Endothelial progenitor cell levels in obese men with the metabolic syndrome and the effect of simvastatin monotherapy vs, simvastatin/ezetimibe combination therapy. Eur Heart J 29: 2808-2817, 2008.

WOJAKOWSKI W, TENDERA M, KUCIA M, ZUBA-SURMA E, PACZKOWSKA E, CIOSEK J, HALASA M, KROL M, KAZMIERSKI M, BUSZMAN P, OCHALA A, RATAJCZAK J, MACHALINSKI B, RATAJCZAK MZ: Mobilization of bone marrow-derived Oct-4+ SSEA-4+ very small embryonic-like stem cells in patients with acute myocardial infarction. $J$ Am Coll Cardiol 53: 1-9, 2009.

WOJAKOWSKI W, TENDERA M, KUCIA M, ZUBA-SURMA E, MILEWSKI K, WALLACE-BRADLEY D, KAZMIERSKI M, BUSZMAN P, HRYCEK E, CYBULSKI W, KALUZA G, WIECZOREK P, RATAJCZAK J, RATAJCZAK MZ: Cardiomyocyte differentiation of bone marrow-derived Oct4+CXCR4+SSEA-1+ very small embryonic-like stem cells. Int J Oncol 37: 237-247, 2010.

WU Q, SHAO H, DARWIN ED, LI J, LI J, YANG B, WEBSTER KA, YU H: Extracellular calcium increases CXCR4 expression on bone marrow-derived cells and enhances pro-angiogenesis therapy. $J$ Cell Mol Med 13: 3764$3773,2009$. 
XIAO Q, KIECHL S, PATEL S, OBERHOLLENZER F, WEGER S, MAYR A, METZLER B, REINDL M, HU Y, WILLEIT J, XU Q: Endothelial progenitor cells, cardiovascular risk factors, cytokine levels and atherosclerosis--results from a large population-based study. PLoS One 2: e975, 2007.

YANG YJ, QIAN HY, HUANG J, GENG YJ, GAO RL, DOU KF, YANG GS, LI JJ, SHEN R, HE ZX, LU MJ, ZHAO SH: Atorvastatin treatment improves survival and effects of implanted mesenchymal stem cells in postinfarct swine hearts. Eur Heart J 29: 1578-1590, 2008.

ZHANG G, NAKAMURA Y, WANG X, HU Q, SUGGS LJ, ZHANG J: Controlled release of stromal cell-derived factor-1alpha in situ increases c-kit+ cell homing to the infarcted heart. Tissue Eng 13: 2063-2071, 2007.

ZHANG S, ZHANG L, SUN A, JIANG H, QIAN J, GE J: Efficacy of statin therapy in chronic systolic cardiac insufficiency: a meta-analysis. Eur J Intern Med 22: 478-484, 2011.

ZUBA-SURMA EK, KUCIA M, DAWN B, GUO Y, RATAJCZAK MZ, BOLLI R: Bone marrow-derived pluripotent very small embryonic-like stem cells (VSELs) are mobilized after acute myocardial infarction. $J$ Mol Cell Cardiol 44: 865-873, 2008. 